\title{
Abundance, Species Composition and Feeding Impact of Tintinnid Micro-Zooplankton in Central Long Island Sound*
}

\author{
Gerard M. Capriulo and Edward J. Carpenter
}

Marine Sciences Research Center, State University of New York, Stony Brook, N. Y. 11794, USA

\begin{abstract}
Abundance and composition of tintinnid and phytoplankton species were followed in central Long Island Sound from August 1979 to October 1980. In all, 28 tintinnid species were observed; the greatest diversity occurred between September and April. Highest tintinnid concentrations occurred in summer, with concentrations of $10^{3}$ or more individuals $l^{-1}$ observed only when nanophytoplankton concentrations equalled or exceeded $1.3 \times 10^{5}$ cells $1^{-1}$. Although necessary, the occurrence of small food, alone, was not a sufficient condition for high tintinnid densities. Tintinnids in central Long Island Sound exhibited the same order of magnitude yearly community ingestion rates as did the copepods. The tintinnids were responsible for removing approximately $27 \%$ of the annual primary production from this region. It is concluded that tintinnids are an integral part of the Long Island Sound plankton community, equal in importance to copepods.
\end{abstract}

\section{INTRODUCTION}

Considerable research has been carried out on the abundance and species composition of tintinnid protozoans in the world's oceans. Tintinnid abundance and composition have been recorded for the Okhotsk Sea (Hada, 1932) the Kuroshio water (Motoda and Marumo, 1963) and the Sea of Japan (Konovalova and Rogachenko, 1975). Sorokin (1977) reported concentrations in the Sea of Japan approaching 15,000 $1^{-1}$. For the Phillippine and Celebes Seas concentrations of 10 to $100 \mathrm{l}^{-1}$ have been reported (Taniguchi, 1977). Studies have also been carried out in the East Sea of the USSR (Strelkov, 1955), the Black Sea (Morozovskaya, 1970), and the Red Sea (Kimor and Golandsky, 1977; Kimor and Golandsky-Baras, 1981). The Baltic area has been investigated by Hensen (1887), Gillbricht (1954) and Halme (1958), with Lohmann (1908) pointing out the apparent significance of certain micro-zooplankton in this area. Hedin (1976) reported concentrations of tintinnids for the Swedish west coast averaging 10 to $15 \mathrm{I}^{-1}$. Similar concentrations were found in the Arabian Sea (Zeitzschel, 1969). The North

\footnotetext{
- Contribution No. 330 of the Marine Sciences Research Center
}

Atlantic Ocean (Zeitzschel, 1967) has also been studied with additional partial surveys carried out for the Northwest Atlantic Ocean (Fornshell, 1979) and North Sea (Lindley, 1975). Concentrations of tintinnids in the California current of about $50 \mathrm{l}^{-1}$ were reported (Beers and Stewart, 1967), with 40 to $2001^{-1}$ encountered in the eastern tropical Pacific Ocean (Beers and Stewart, 1971). Beers et al. (1980) carried out additional research in southern California nearshore waters. Tintinnid concentrations as high as $18,0001^{-1}$ were reported for the southern California Bight (Heinbokel and Beers, 1979). Concentrations of 100 to 1,000 individuals $1^{-1}$ were observed in the Peruvian coastal waters (Beers et al., 1971). Tintinnid densities in the eastern Mediterranean Sea reaching 30,000 $\mathrm{l}^{-1}$ were found by Vitiello (1964), demonstrating the extremely high concentrations these organisms can reach in the field.

Until recently, little information on tintinnid composition and abundance could be found for the coastal regions of the eastern United States. Gold and Morales (1975) presented a qualitative analysis of the tintinnids of the New York Bight over a yearly cycle. Hargraves (1981) reported data on abundance and species composition over several months for Narragansett Bay, Rhode Island. While the data for the areas discussed 
above are important, little information on temporal variation can be found.

Theoretical calculations, based on numerical abundance data and assumptions concerning feeding rates of eastern tropical Pacific micro-zooplankton, suggest that at times these organisms may consume as much as $70 \%$ of the daily phytoplankton organic carbon production (Beers and Stewart, 1971). For Long Island Sound, Riley (1956) estimated that perhaps as much as $43 \%$ of the net carbon fixed annually by photosynthesis may be removed by the micro-zooplankton and bacteria in the water column. Data of Capriulo and Carpenter (1980) for central Long Island Sound indicated that the micro-zooplankton (consisting predominantly of tintinnids) removed up to $41 \%$ of the chlorophyll a standing crop per day and, at times, exhibited community ingestion rates equal to those of the copepod community. Heinbokel and Beers (1979), using data from Heinbokel $(1978 \mathrm{a}$, b), estimated that the tintinnids in the Southern California Bight were capable of ingesting approximately $4 \%$ to $20 \%$ of the daily primary production.

This paper is concerned with enhancement of the current understanding of tintinnid community structure in Long Island Sound. Abundance and species composition of tintinnids measured at a central Long Island Sound station from July 1979 through October 1980 are presented in relation to associated phytoplankton abundance and composition. These data, along with information on ingestion rates of field collected tintinnids feeding on natural food (Capriulo, 1982) and data on copepod abundance and feeding in Long Island Sound, are used to quantify and compare the grazing impact of these two important groups of herbivores.

\section{MATERIALS AND METHODS}

This study was conducted as part of a larger endeavor which included the measurement of ingestion rates of field-collected tintinnids feeding on natural food (Capriulo, 1982) and a comparison of the feeding activities of field-collected tintinnids and copepods fed identical natural food (Capriulo and Ninivaggi, 1982). All sampling was carried out at a station in Long Island Sound (Station A, Fig. 1) in water $31 \mathrm{~m}$ deep. Water samples were collected from 1 and $5 \mathrm{~m}$ depths in $10 \mathrm{l}$ Niskin bottles and from the surface in plastic buckets. The temperature of all samples was recorded.

Particle-size/biomass distributions were determined by means of a Particle Data Inc. ${ }^{\circledR}$ automated electronic counting system consisting of a high resolution 128 channel analyzer interfaced with a PDP8 computer. Calibrated 190 and $380 \mu \mathrm{m}$ orifice tubes were utilized

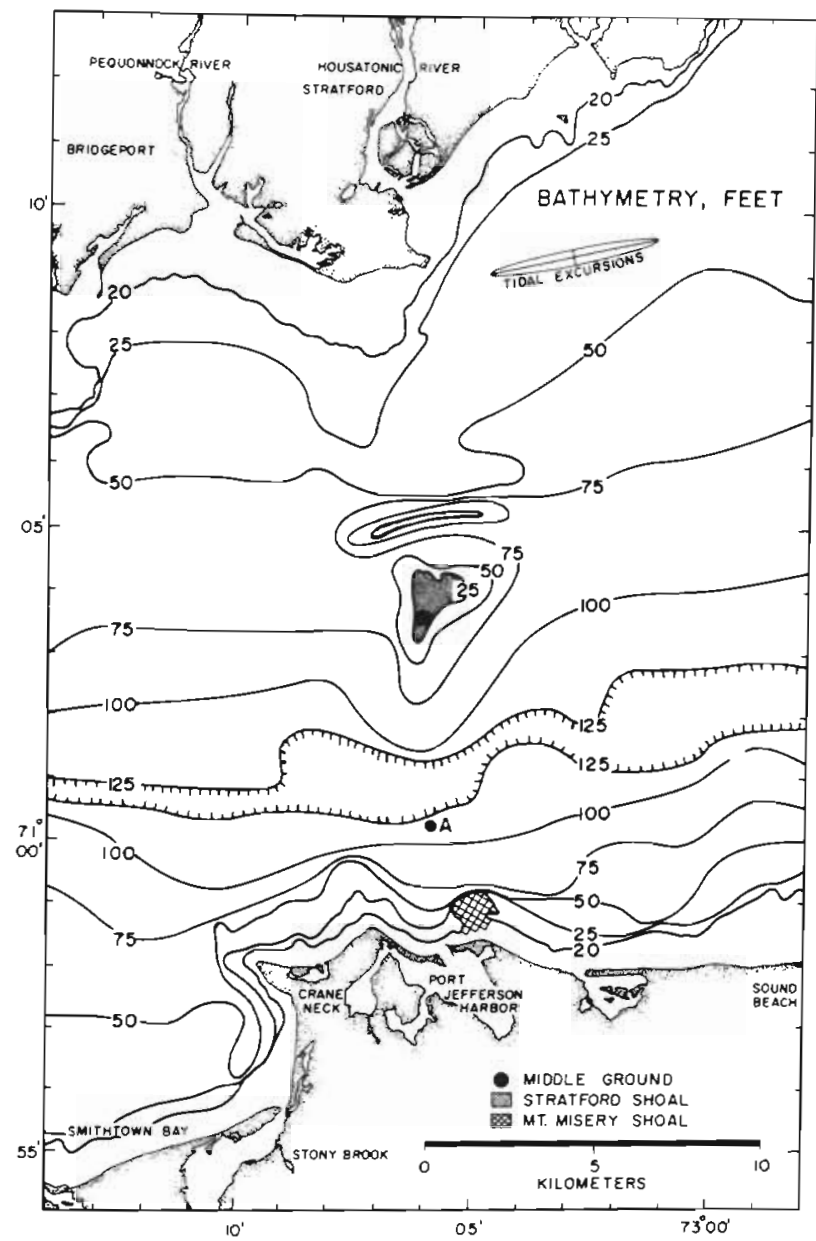

Fig. 1. Study area (Station A), located $3.6 \mathrm{~km}$ outside of Port Jefferson Harbor (water $31 \mathrm{~m}$ deep) in central Long Island Sound

and the resulting data sets blended. Some of the limitations imposed by the use of particle counters are discussed in Capriulo (1982) and Capriulo and Ninivaggi (1982)

Subsamples of the counted material were fixed with Lugol's solution and later analyzed microscopically to determine both phytoplankton and micro-zooplankton composition. For the phytoplankton, $15 \mathrm{ml}$ of $100 \mathrm{ml}$ subsamples were centrifuged for several hours, concentrating the cells in a final volume of $1 \mathrm{ml}$. The $1 \mathrm{ml}$ concentrate was introduced into a Sedgwick-Rafter cell and random strips were analyzed, at $500 \times$ magnification, to determine species composition and abundance. Counting error was estimated according to the method of Lund et al. (1958). For the micro-zooplankton, 2.5 I of sample were fixed, placed in graduated cylinders and allowed to settle for several days. The supernatant was removed by aspiration until a final volume of $100 \mathrm{ml}$ was achieved. Of this concentrated sample 25 to $50 \mathrm{ml}$ were centrifuged at $100 \times$ 


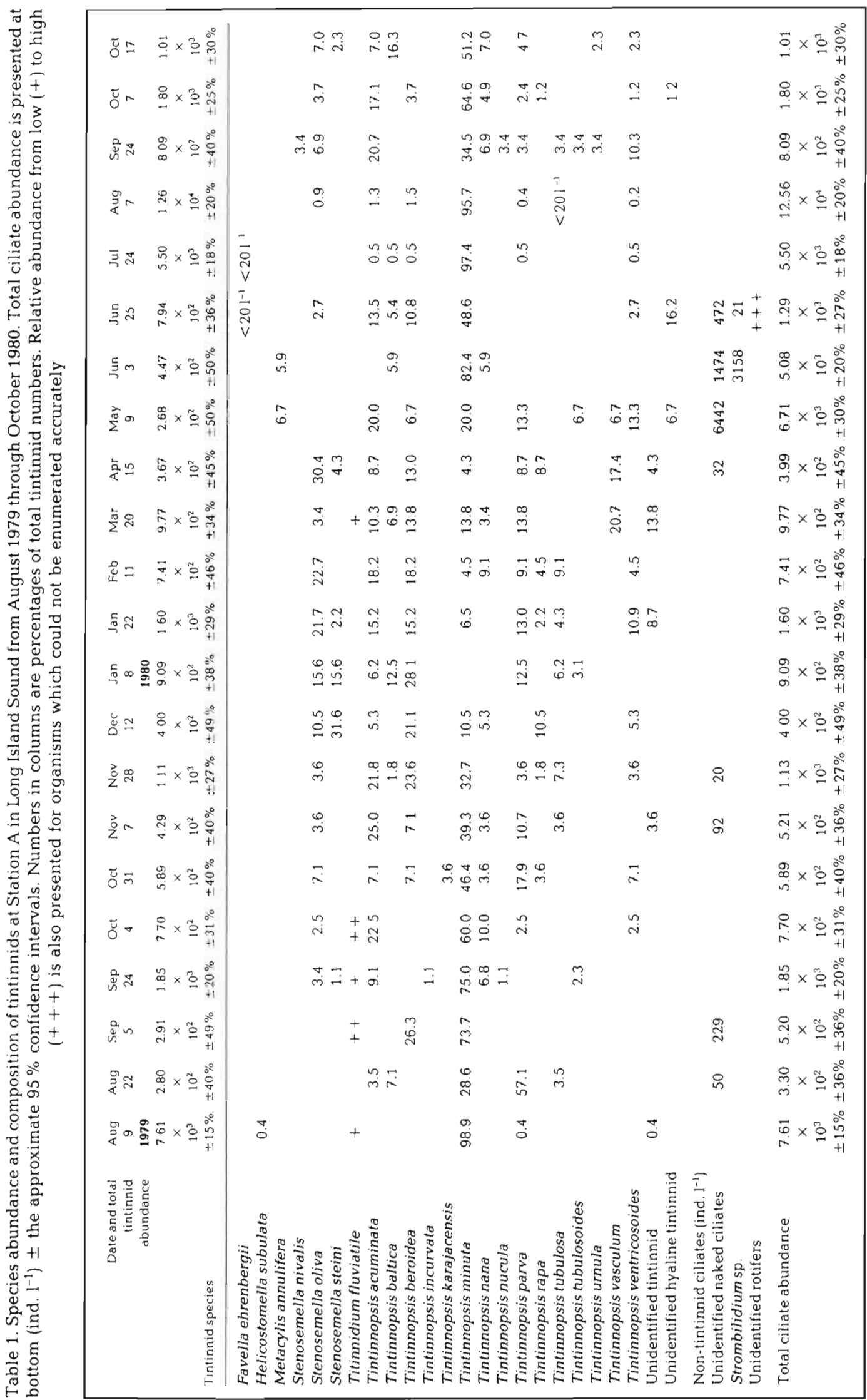


gravity for about $2 \mathrm{~h}$. Again the supernatant was drawn off until $1 \mathrm{ml}$ remained. The concentrate was then introduced into a Sedgwick-Rafter cell and analyzed as outlined above for the phytoplankton.

\section{RESULTS}

\section{Tintinnid Species Abundance and Composition}

Total tintinnid abundance in the upper $1 \mathrm{~m}$ of water at Station $A$, in central Long Island Sound, varied from 268 to $126001^{-1}$ throughout the year, with 24 species in all having been encountered (Table 1, Fig. 2). The highest concentrations (5500 to 12600 individuals $l^{-1}$, for both years of this study occurred during July and August during the temperature maximum (Fig. 2). Tintinnid composition on these occasions was completely dominated ( $96 \%$ to $99 \%$ ) by the small tintinnid Tintinnopsis minuta $(13 \mu \mathrm{m}$ wide and $\simeq 18 \mu \mathrm{m}$ long). Ciliates other than tintinnids occasionally were predominant with highest concentrations $\left(=6000^{-1}\right)$ observed in May and June just prior to the surge in abundance of $T$. minuta in July (Fig. 2, Table 1). In addition, rotifers,

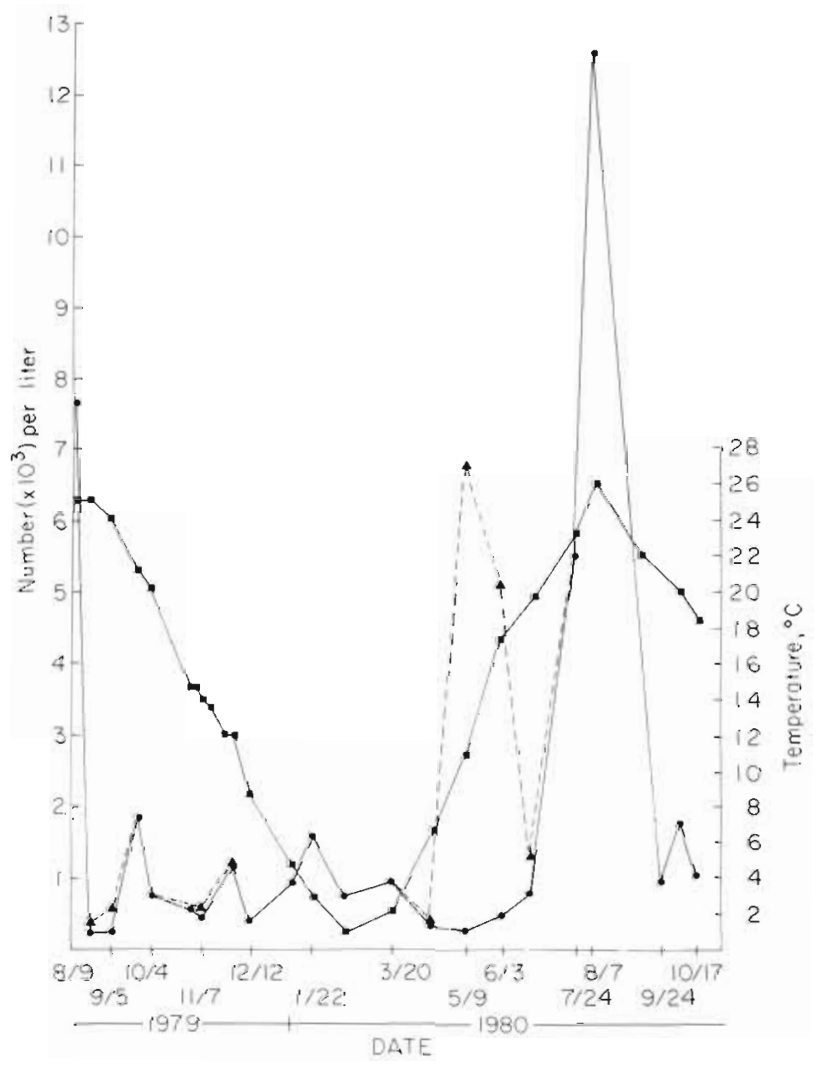

Fig. 2. Profile of total tintinnid abundance (solid circles), total ciliate abundance (solid triangles) and surface-water temperature (solid squares) at Station $\mathrm{A}$ in Long Island Sound (August 1979 to October 1980) which did not preserve well and therefore could not be quantified, were found to be the dominant small grazers at times.

\section{Phytoplankton Species Abundance and Composition}

The seasonally shifting particle spectrum (Fig. 3) and corresponding phytoplankton species composition (Table 2) show the succession of both food size and type at Station A. The less than 10 m material for all sampling dates was composed predominantly of various monads (cryptomonads, calycomonads, chroomonads) and other small flagellates. Concentrations of phytoplankton varied from $8 \times 10^{4}$ cells $1^{-1}$ to $4 \times 10^{6}$ cells $1^{-1}$. Phytoplankton succession followed a general pattern similar to that described by Conover (1956) for Long Island Sound. Diatoms were found through much of the year but attained their highest concentrations in January through April and again in September through October. Dinoflagellates peaked in June and persisted into August. The nanoplankton reached their highest concentrations from May through August with peaks also occurring in winter (Table 2).

\section{Correlation Between Tintinnid and Phytoplankton Abundance}

Tintinnid density (Fig. 4) and size (Fig. 5) were found to be unrelated to the size of the food material comprising the biomass peaks. Since food must first pass through the oral opening of a lorica before it is ingested, the oral diameter measurement (a conservative property of a tintinnid which varies little within a species) was used to represent size for this analysis.

Although there was some correlation between tintinnid density and phytoplankton density the relationship was weak both when tintinnid abundance was compared to the total concentration of phytoplankton (correlation coefficient $r=.31$ ) and when compared to concentration of $\leq 20 \mu \mathrm{m}$ nanophytoplankton (correlation coefficient $r=.20$ ) (Fig. 6). Nanoplankton were present in variable concentration throughout most of the year (Table 2). Analysis of Tables 1 and 2 and Fig, 2 indicates that highest tintinnid concentrations always occurred when nanoplankton were present in high

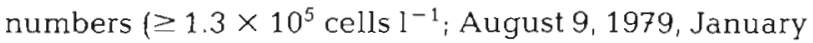
22. July 24 at $1 \mathrm{~m}$ depth, August 7 at $1 \mathrm{~m}$ depth, October 7 and October 17, 1980). However, equivalent concentrations of nanoplankton at other times were not accompanied by high tintinnid densities. The occurrence of small food alone, therefore, while necessary is not a sufficient condition for high tintinnid abundance. Analysis of Tables 1 and 2 indicates that the type of 


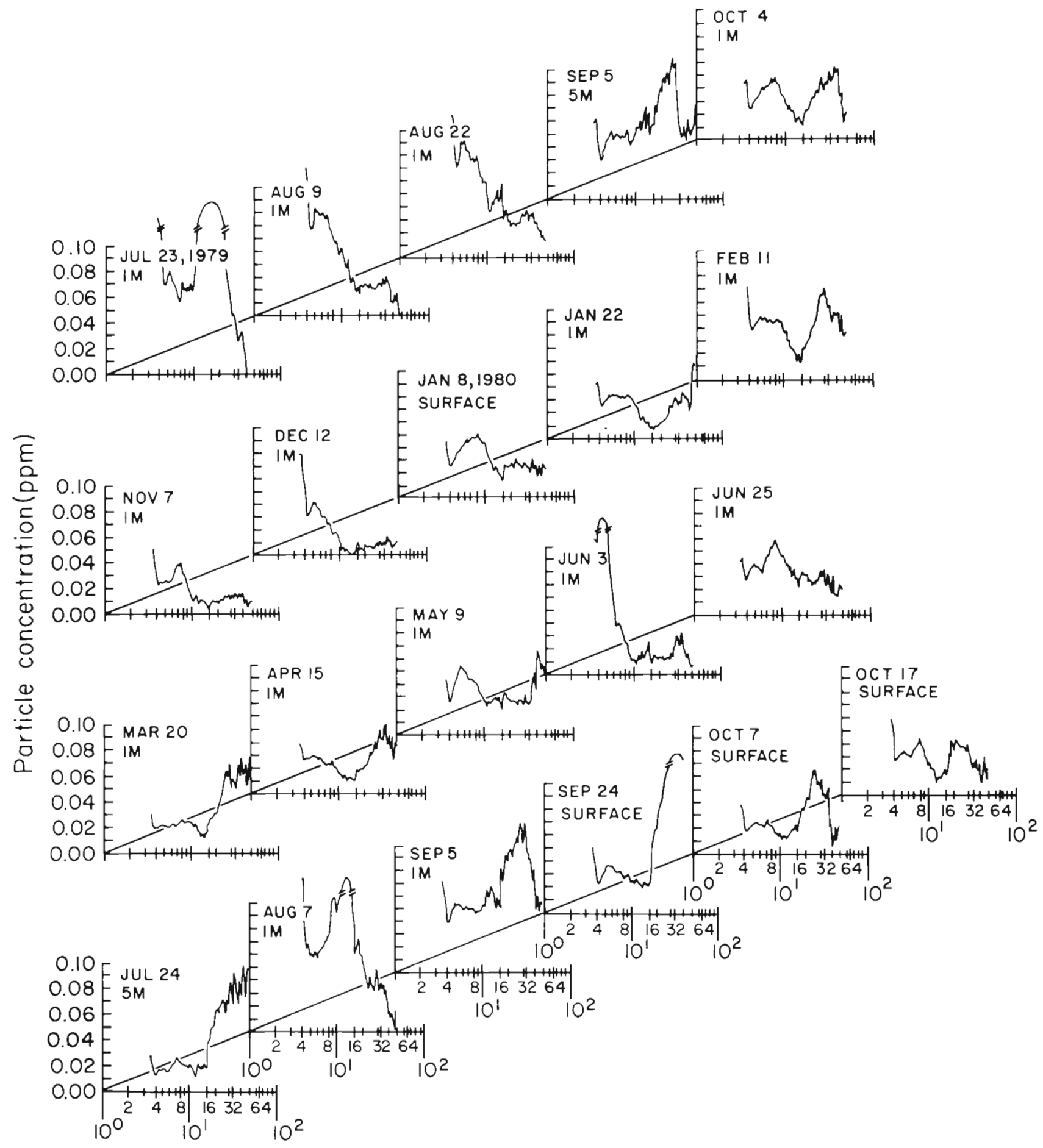

Size in microns

Fig. 3. Particle-size/biomass spectra at Station A from July 1979 through October 1980. Biomass is presented in units of parts per million (ppm) which is equivalent to a particle volume of $1 \mu^{3} \mathrm{~m}^{-3}$ of seawater. Samples taken from surface, $1 \mathrm{~m}$ or $5 \mathrm{~m}$ water depth 


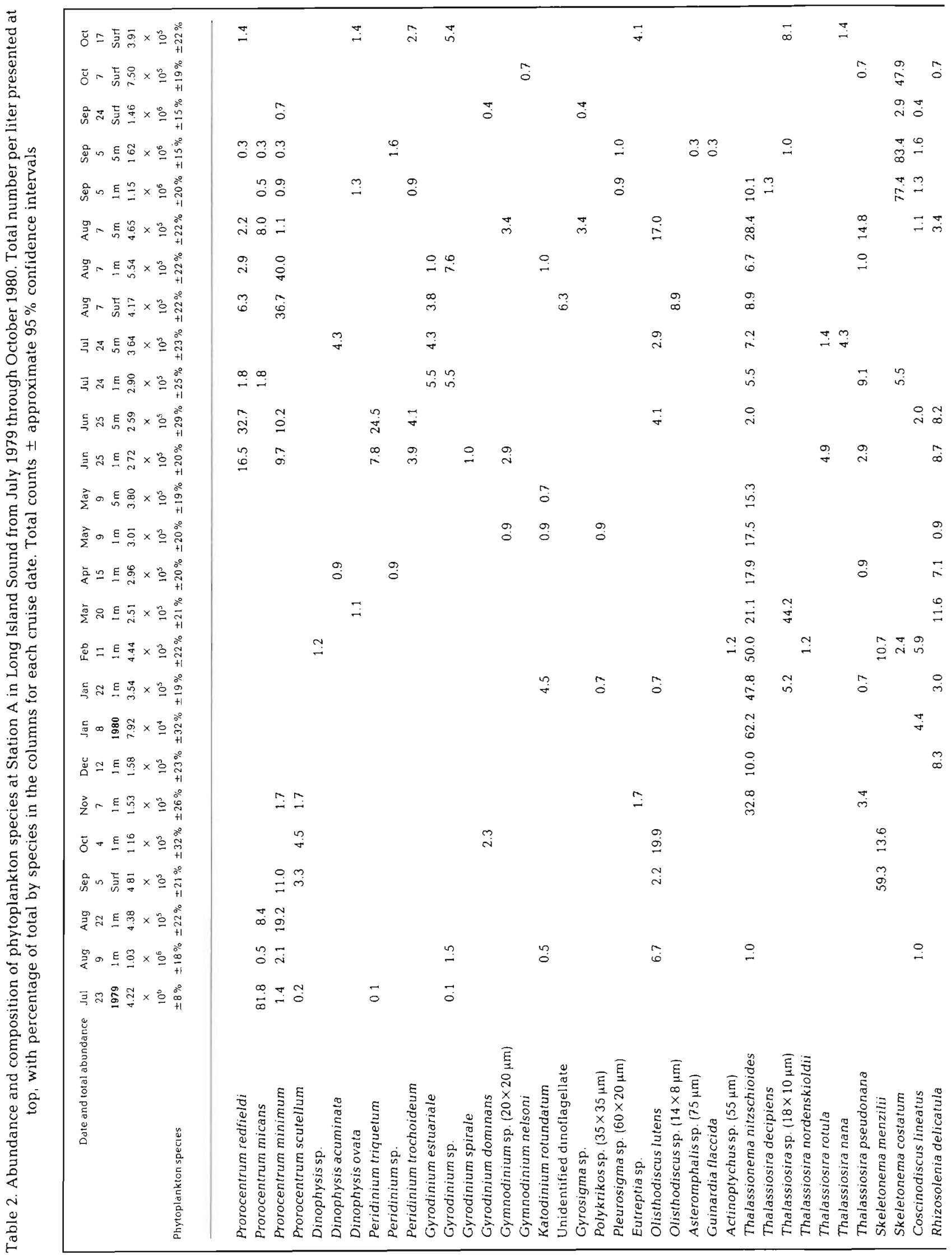




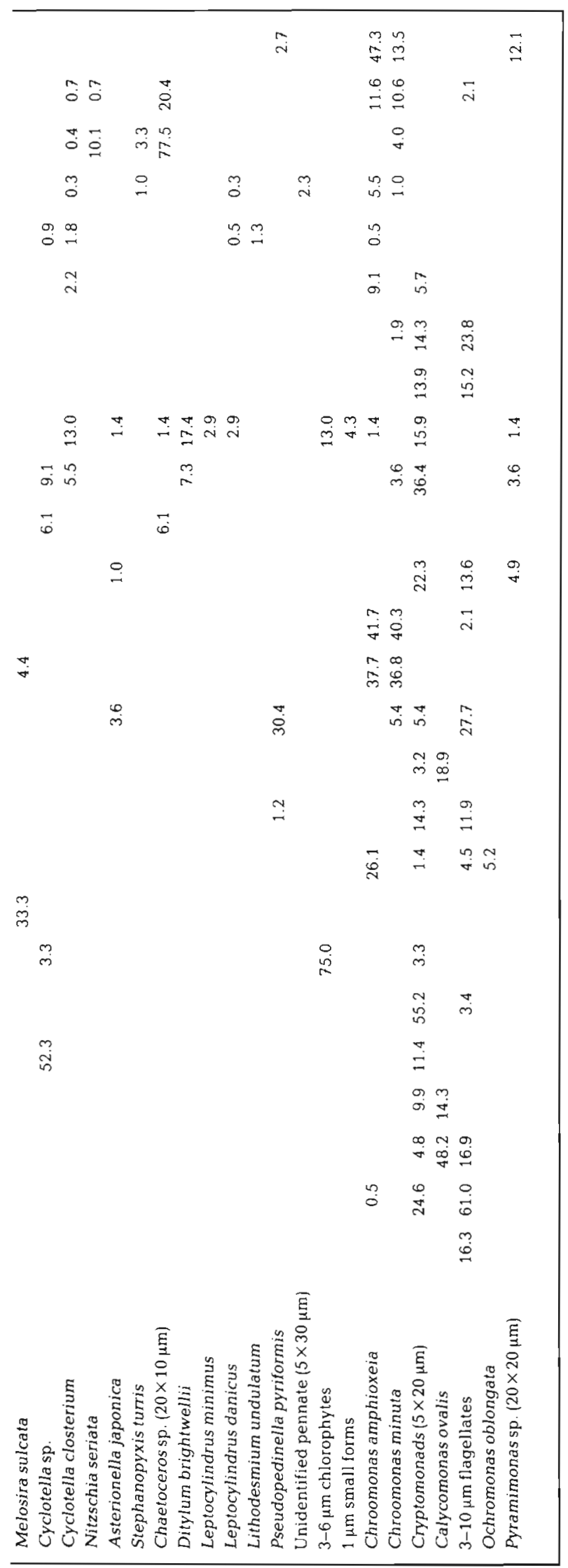

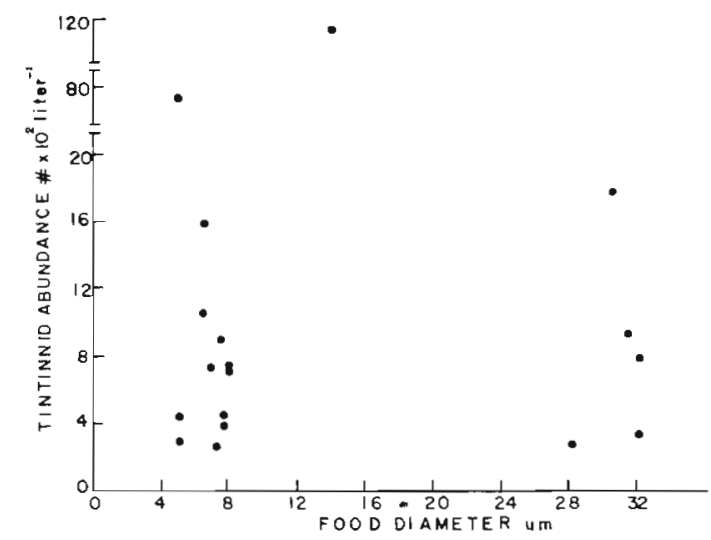

Fig. 4. Tintinnid abundance (number $\times 10^{2}$ cells $1^{-1}$ ) as a function of the size (equivalent spherical diameter) of the natural food-biomass peak

small food does not appear to be critical for high tintinnid densities, since several food spectra, dominated by different nanoplankters, all supported tintinnid densities in the $10^{3} 1^{-1}$ range.

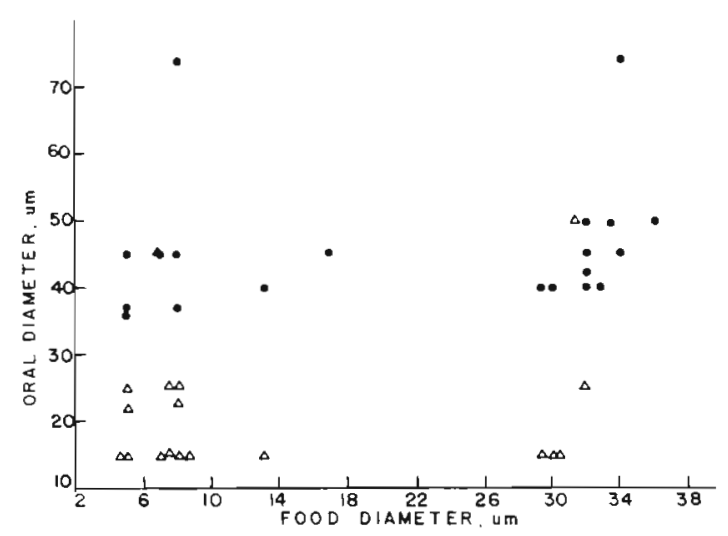

Fig. 5. Tintinnid oral diameter as a function of the size of the natural food-biomass peak (circle: largest, triangle: most abundant tintinnid species)

\section{DISCUSSION}

\section{Phytoplankton and Tintinnid Species Abundance and Composition}

The gross pattern of phytoplankton succession observed in this study is similar to that pattern described for central Long Island Sound by Conover (1956) in her earlier study of Long Island Sound phytoplankton. In general there is a characteristic spring diatom bloom (January or February) followed by nanoplankton and later (June and July) dinoflagellate blooms, with an additional fall (September through October) diatom bloom.

A finer scale comparison of species composition also 
shows strong similarities. Similar patterns of occurrence were observed for Rhizosolenia delicatula, Thalassiosira decipiens, Melosira sulcata, T. nordenskioldii, Asterionella japonica, Thalassionena nitzschioides, Peridinium trochoideum and Prorocentrum scutellum. However, many of the species clas-

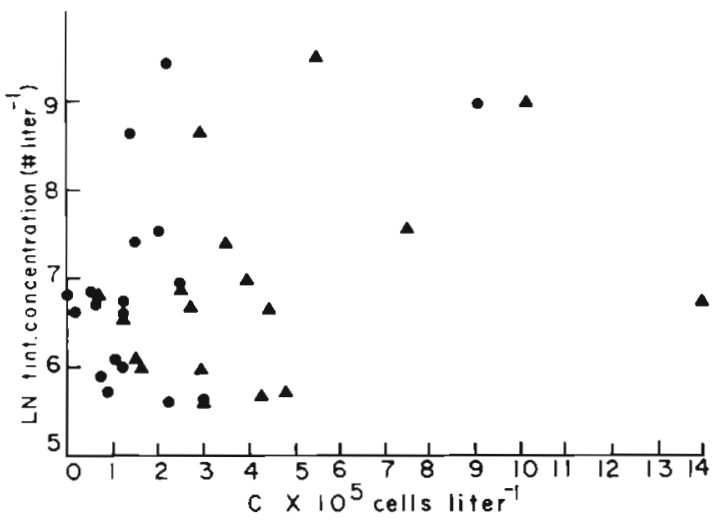

Fig. 6. Natural logarithm of tintinnid abundance (no. $\mathrm{l}^{-1}$ ) versus total phytoplankton (solid triangles) and less than or equal to $20 \mu \mathrm{m}$ phytoplankton (solid circles) concentration (C) in units of $10^{5}$ cells $1^{-1}$ Correlation coefficients for the 2 relationships are $r=.31$ and $r=.20$, respectively

sified by Conover as major species were not encountered in this study. For example, Cerataulina pelagica, several species of Chaetoceros, Asterionella formosa, Corethron criophilum, Lauderia borealis, Rhizosolenia fragilissima, Schroderella delicatula, Thalassiosira gravida, Nitzschia longissima, Exuviella apora and Peridinium elongatum were not observed.

The seasonal pattern of tintinnid abundance reported here, with a range of $2.68 \times 10^{2}$ to $1.26 \times 10^{4}$ tintinnids $\mathrm{I}^{-1}$, is similar to that found in Narragansett Bay (Hargraves, 1981). In all, 28 species (4 additional species, Tintinnopsis dadayi, $T$, levigata, Tintinnus pectinis and Proplectella sp., were also found in Long Island Sound at times not covered by this study) have been encountered. This compares with 32 species reported for Narragansett Bay (Hargraves, 1981) and 34 species for the New York Bight (Gold and Morales, 1975). The greatest species diversity for the New York Bight was found in October with high diversity, with the exception of December, occurring from late September through May. These findings are similar to those of this study where diversity was high between September and April. This contrasts with Hargrave's findings of highest diversity in summer (July and August) in Narragansett Bay. Tintinnopsis minuta was the dominant tintinnid in July and August for all 3 study areas. This species persisted through October and November, although in reduced numbers, for both Long Island Sound and Narragansett Bay, while being observed only through August in the New York Bight.

The species encountered in Long Island Sound were similar to those of the New York Bight and Narragansett Bay regions. Stenosemella ventricosa, Tintinnopsis kofoidii, $T$. platensis and $T$. undella were found both in the New York Bight and Narragansett Bay but not in Long Island Sound. In addition, T. fimbriota, $T$. sufflata and Helicostomella fusiformis were found in Narragansett Bay and Favella arcuata, Metacylis angulata, Ptychocylis obtusa, Parafavella gigantea, P. parumdentata, Parundella sp. and Coxliella sp. in New York Bight but not in Long Island Sound. The same 5 species (Stenosemella nivalis, Tintinnopsis incurvata, T. nana and Proplectella sp.) were present in Long Island Sound samples but not in either the New York Bight or

Table 3. Yearly volume ingestion rates for copepods of central Long Island Sound. Copepod abundance taken from Figs. 3 and 5 of Deevey (1956). Ingestion rates assigned as described in text. A copepod abundance $\left(\# \mathrm{~m}^{-3}\right)_{i} \mathrm{I}$ ingestion rate $\times 10^{6} \mu \mathrm{m}^{3}$ copepod $^{-1} \mathrm{~d}^{-1} ; \mathrm{V}$ average daily ingestion rate $\times 10^{10} \mu \mathrm{m}^{3}$ by species for the appropriate season. Winter $=$ December, January, February $(90 \mathrm{~d})$; spring = March, April, May (92 d); summer = June, July, August $(92 \mathrm{~d})$; fall = September, October, November (91 d)

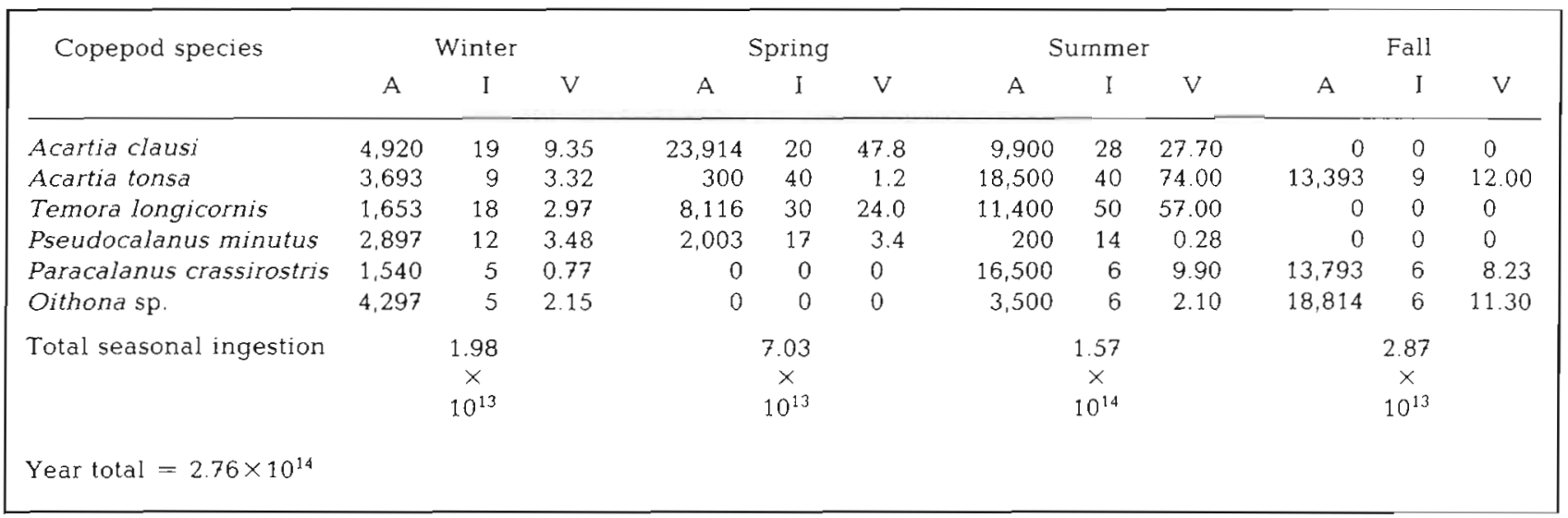


Table 4. Yearly volume ingestion rates for tintinnids of central Long Island Sound. Tintinnid abundance from present study. Ingestion rates from regression equation of Fig. 21, Capriulo (1982). A tintinnid abundance $\left(\# \mathrm{~m}^{-3}\right)$; I ingestion rate $\times 10^{6} \mu \mathrm{m}^{3}$ tintinnid ${ }^{-1} \mathrm{~d}^{-1}$; V average daily ingestion rate $\times 10^{10} \mu \mathrm{m}^{3}$ by species for the appropriate season. Seasons divided as in Table 3

\begin{tabular}{|c|c|c|c|c|c|c|c|c|c|c|c|c|}
\hline \multirow[t]{2}{*}{ Tintinnid species } & \multicolumn{3}{|c|}{ Winter } & \multicolumn{3}{|c|}{ Spring } & \multicolumn{3}{|c|}{ Summer } & \multicolumn{3}{|c|}{ Fall } \\
\hline & A & I & v & A & I & V & A & I & V & A & I & V \\
\hline Stenosemella oliva & 151,569 & 0.42 & 6.37 & 72,393 & 0.42 & 3.04 & 16,173 & 0.42 & 0.68 & 38,956 & 0.42 & 1.64 \\
\hline S. steini & 71,634 & 0.35 & 2.51 & 5.260 & 0.35 & 0.18 & 0 & - & - & 4,197 & 0.35 & 0.15 \\
\hline Tintinnopsis acuminata & 101,947 & 0.05 & 0.51 & 62,053 & 0.05 & 0.31 & 46,320 & 0.05 & 0.23 & 144,982 & 0.05 & 0.72 \\
\hline T. beroidea & 156,192 & 0.34 & 5.31 & 66,831 & 0.34 & 2.27 & 44,459 & 0.34 & 1.51 & 60,725 & 0.34 & 2.06 \\
\hline T. minuta & 59,782 & 0.23 & 1.38 & 68,069 & 0.23 & 1.60 & $4.1 \times 10^{6}$ & 0.23 & 94.30 & 498,863 & 0.23 & 11.47 \\
\hline T. nana & 29,544 & 0.23 & 0.68 & 11,073 & 0.23 & 0.25 & 4,396 & 0.23 & 0.10 & 44,179 & 0.23 & 1.02 \\
\hline T. rapa & 36,848 & 0.38 & 1.40 & 10,643 & 0.38 & 0.40 & 0 & - & - & 6,947 & 0.38 & 0.26 \\
\hline T. vasculum & 0 & - & - & 94,684 & 0.08 & 0.76 & 0 & - & - & 0 & - & - \\
\hline$T$ baltica & 37,875 & 0.37 & 1.40 & 22,471 & 0.37 & 0.83 & 22,917 & 0.37 & 0.85 & 12,365 & 0.37 & 0.46 \\
\hline T. parva & 76,081 & 1.30 & 9.90 & 67,466 & 1.30 & 8.77 & 35,913 & 1.30 & 4.67 & 35,413 & 1.30 & 4.60 \\
\hline T. tubulosa & 43,336 & 0.37 & 1.60 & 0 & - & - & 3,311 & 0.37 & 0.12 & 25,248 & 0.37 & 0.93 \\
\hline T. tubulosoides & 9,393 & 0.38 & 0.36 & 5,985 & 0.38 & 0.23 & 0 & - & - & 7,784 & 0.38 & 0.30 \\
\hline$T$. ventricosoides & 69,955 & 0.38 & 2.66 & 11,881 & 0.38 & 0.45 & 15,540 & 0.38 & 0.59 & 24,794 & 0.38 & 0.94 \\
\hline Unid tint. & 46,400 & 0.28 & 1.30 & 50,202 & 0.28 & 1.41 & 3,382 & 0.28 & 0.09 & 2,574 & 0.28 & 0.07 \\
\hline Metacylis annulifera & 0 & - & - & 5,985 & 0.34 & 0.20 & 4,395 & 0.34 & 0.15 & 0 & - & - \\
\hline Unid. hyaline tint. & 0 & - & - & 5,985 & 0.14 & 0.08 & 21,438 & 0.14 & 0.30 & 1,800 & 0.14 & 0.03 \\
\hline Favella ehrenbergii & 0 & - & - & 0 & - & - & 10,000 & 0.17 & 0.17 & 0 & - & - \\
\hline Helicostomella subulata & 0 & - & - & 0 & - & - & 3,383 & 0.81 & 0.27 & 0 & - & - \\
\hline Stenosemella nivalis & 0 & - & - & 0 & - & - & 0 & - & - & 3,056 & 0.34 & 0.10 \\
\hline Tintinnopsis incurvata & 0 & - & - & 0 & - & - & 0 & - & - & 2,261 & 0.39 & 0.09 \\
\hline Tintinnopsis nucula & 0 & - & - & 0 & - & - & 0 & - & - & 5,317 & 0.38 & 0.20 \\
\hline Tintinnopsis urnula & 0 & - & - & 0 & - & - & 0 & - & - & 4,993 & 0.37 & 0.18 \\
\hline Tintinnopsis karajacensis & 0 & - & - & 0 & - & - & 0 & - & - & 1,767 & 0.39 & 0.07 \\
\hline Total seasonal ingestion & \multicolumn{3}{|c|}{$3.18 \times 10^{13}$} & \multicolumn{3}{|c|}{$1.91 \times 10^{13}$} & \multicolumn{3}{|c|}{$9.57 \times 10^{13}$} & \multicolumn{3}{|c|}{$2.30 \times 10^{13}$} \\
\hline
\end{tabular}

Narragansett Bay. Also, T. levigata was found in Long Island Sound and not in Narragansett Bay. Only 1 specimen of $T$. incurvata was observed and therefore the identification cannot be considered conclusive. Ptychocyles, Coxliella and Parundella are typical coastal forms and their absence from an estuary is not unusual. The boundaries between species are sometimes very ambiguous. Helicostomella subulata and $H$. fusiformis are considered by some to be synonymous (Hargraves, 1981). In addition, T. beroidea, T. minuta, $T$. nana, $T$. parvula and T. rapa may be variations of the same species (Baker and Phaff, 1976), as may be the case for $T$. lobiancoi, $T$. tubulosa, $T$. karajacensis and T. tubulosoides. Similar problems of identification are encountered in the genera Favella (Laval-Peuto, 1981) and Ptychocylis (Davis, 1981). These problems in taxonomy may account for some of the differences in species lists from different areas.

This study, along with those of Vitiello (1964), Beers and Stewart (1967), Heinbokel and Beers (1979), Capriulo and Carpenter (1980), Hargraves (1981) and Margalef (1982), demonstrates that the concentrations of tintinnids found in the coastal zone are substantially higher than those reported for the open ocean. One reason for this difference may be cell sinking. The tintinnid lorica (particularly agglutinated types which have láge amounts of attached nonbiogenic and biogenic particles; Gold and Morales, 1976) adds substantial weight to these organisms (Margalef, 1982) thus increasing their sinking rates (increased weight and associated sinking may represent an evolutionary adaptation affording tintinnids a means of escape from predation, Capriulo et al., 1982). It is possible that the high advective energy associated with coastal waters counteracts sinking to some extent by keeping tintinnids in suspension for longer periods of time than would be possible in less turbulent open ocean waters. In this way, tintinnids may survive better by remaining in the euphotic zone with the phytoplankton on which they feed. Since decreases in tintinnid abundance offshore are accompanied by decreases in phytoplankton concentrations (Beers et al., 1980) the above hypothesis cannot yet be confirmed. Verification awaits an analysis of the ratio of aloricate ciliate concentration to tintinnid concentration as a function of water column mixing intensity. Since aloricate ciliates are not as dependent on turbulence for maintenance of water column position as are their heavier relatives, their abundance should increase relative to the tintinnids, in low turbulence environments. 
Table 5. Measurements of width (oral diameter, OD) and length ( $\mu \mathrm{m}$ ) for all tintinnids encountered in this study. Lorica volume calculated assuming a half ellipsoid shape. Animal volume assumed to be equal to half the lorica volume with a specific weight of 1 (Beers and Stewart, 1969; Hedin, 1976). Dry weight assumed to equal 20\% wet weight (Cushing et al., 1958)

\begin{tabular}{|c|c|c|c|c|c|c|}
\hline Tintinnid species & $\begin{array}{l}\mathrm{OD} \\
(\mu \mathrm{m})\end{array}$ & $\begin{array}{c}\mathrm{L} \\
(\mu \mathrm{m})\end{array}$ & $\begin{array}{c}\text { Lorica } \\
\text { volume }\left(\mu \mathrm{m}^{3}\right)\end{array}$ & $\begin{array}{c}\text { Animal } \\
\text { volume }\left(\mu \mathrm{m}^{3}\right)\end{array}$ & $\begin{array}{c}\text { Wet wt. } \\
(\mu \mathrm{g})\end{array}$ & $\begin{array}{l}\text { Dry wt. } \\
\text { (ng) }\end{array}$ \\
\hline Favella ehrenbergii & 75 & 200 & $5.89 \times 10^{5}$ & $2.9 \times 10^{5}$ & .290 & 58.0 \\
\hline Helicostomella subulata & 22 & 250 & $6.33 \times 10^{4}$ & $2.1 \times 10^{4}$ & .021 & 4.2 \\
\hline Metacylis annulifera & 21 & 40 & $9.20 \times 10^{3}$ & $4.6 \times 10^{3}$ & .005 & 1.0 \\
\hline Stenosemella nivalis & 21 & 40 & $9.20 \times 10^{3}$ & $4.6 \times 10^{3}$ & .005 & 1.0 \\
\hline S. oliva & 25 & 50 & $1.64 \times 10^{4}$ & $8.2 \times 10^{3}$ & .008 & 1.6 \\
\hline S. steini & 25 & 60 & $6.08 \times 10^{4}$ & $3.0 \times 10^{4}$ & .030 & 6.0 \\
\hline Tintinnidium fluviatile & 45 & 95 & $1.00 \times 10^{5}$ & $5.0 \times 10^{4}$ & .050 & 10.0 \\
\hline Tintinnopsis acuminata & 22 & 35 & $8.90 \times 10^{3}$ & $4.4 \times 10^{3}$ & .004 & 0.8 \\
\hline T. baltica & 36 & 60 & $4.10 \times 10^{4}$ & $2.1 \times 10^{4}$ & .021 & 4.2 \\
\hline T. beroidea & 23 & 34 & $9.40 \times 10^{3}$ & $4.7 \times 10^{3}$ & .005 & 1.0 \\
\hline T. incurvata & 24 & 90 & $2.70 \times 10^{4}$ & $1.4 \times 10^{4}$ & .014 & 2.8 \\
\hline T. karajacensis & 25 & 100 & $3.30 \times 10^{4}$ & $1.6 \times 10^{4}$ & .016 & 3.2 \\
\hline$T$. minuta & 15 & 30 & $3.50 \times 10^{3}$ & $1.8 \times 10^{3}$ & .002 & 0.4 \\
\hline T. nana & 16 & 24 & $3.20 \times 10^{3}$ & $1.6 \times 10^{3}$ & .002 & 0.4 \\
\hline T. nucula & 29 & 45 & $2.04 \times 10^{4}$ & $1.0 \times 10^{4}$ & .010 & 4.0 \\
\hline T. parva & 25 & 38 & $1.20 \times 10^{4}$ & $6.0 \times 10^{3}$ & .006 & 1.2 \\
\hline T. rapa & 25 & 50 & $1.60 \times 10^{4}$ & $8.0 \times 10^{3}$ & .008 & 1.6 \\
\hline T. tubulosa & 37 & 60 & $4.30 \times 10^{4}$ & $2.1 \times 10^{4}$ & .021 & 4.2 \\
\hline T. tubulosoides & 37 & 46 & $3.30 \times 10^{4}$ & $1.7 \times 10^{4}$ & .017 & 3.4 \\
\hline T. urnula & 42 & 50 & $4.60 \times 10^{4}$ & $2.3 \times 10^{4}$ & .023 & 4.6 \\
\hline T. vasculum & 48 & 60 & $7.20 \times 10^{4}$ & $3.6 \times 10^{4}$ & .036 & 7.2 \\
\hline T. ventricosoides & 38 & 50 & $3.80 \times 10^{4}$ & $1.9 \times 10^{4}$ & .019 & 3.8 \\
\hline Unid. tint. & 22 & 24 & $6.00 \times 10^{3}$ & $3.0 \times 10^{3}$ & .003 & 0.6 \\
\hline Unid. hyaline tint & 15 & 19 & $2.20 \times 10^{3}$ & $1.1 \times 10^{3}$ & .001 & 0.2 \\
\hline
\end{tabular}

\section{Relative Importance of Tintinnid and Copepod Ingestion}

A first approximate comparison of the yearly ingestion rate of the tintinnids and copepods of central Long Island Sound can be made, using tintinnid abundance data presented in this study (Table 1) and the abundance data for copepods in central Long Island Sound presented by Deevey (1956: Figs. 3 and 5). To accomplish this, a year was broken up into 4 seasons as follows: winter including December, January and February (total of $90 \mathrm{~d}$ ); spring including March, Apríl and May (total of $92 \mathrm{~d}$ ); summer including June, July and August (total of $92 \mathrm{~d}$ ); fall including September, October and November (total of $91 \mathrm{~d}$ ). Individual species concentrations were averaged over each 3 mo season to give an average season abundance value per species per $\mathrm{m}^{3}$ (Table 3 for copepods, Table 4 for tintinnids). Ingestion rates were then assigned to each species.

Data on copepod ingestion rates, based on particle volume food concentrations found in this study, were extracted from O'Connors et al. (1976) for Acartia clausi, from the data of Capriulo and Ninivaggi (1982) for Acartia tonsa, from O'Connors et al. (1980) for Temora longicornis and from Mayzaud and Poulet (1978) for Oithona sp. and Pseudocalanus minutus.
Ingestion rates for Paracalanus crassirostris, a copepod similar in size to Oithona similis, were estimates from rates reported for $O$. similis by Mayzaud and Poulet (1978). Tintinnid ingestion rates were taken from the weight specific ingestion rate versus dry body weight regression equation of Fig. 21 of Capriulo (1982). Tintinnid body weights were taken from the calculated weights of Table 5 . It was assumed that dry weight is equal to $20 \%$ wet weight and that specific weight is equal to 1 (Cushing et al., 1958; Beers and Stewart, 1969; Hedin, 1976). Appropriate ingestion rates are presented in Table 3 for copepods and in Table 4 for tintinnids.

Daily ingestion rates for all species studied were summed for each season and then multiplied by the number of days corresponding to that season. Summation of the 4 seasonal totals was then carried out (Tables 3 and 4 for copepods and tintinnids, respectively). Comparison of the yearly totals, $2.8 \times 10^{14} \mathrm{um}$ $\mu \mathrm{m}^{3}$ ingested per $\mathrm{m}^{3}$ for copepods and $1.7 \times 10^{14} \mu \mathrm{m}^{3}$ per $\mathrm{m}^{3}$ for tintinnids, demonstrates that both groups are removing the same order of magnitude amount of food and in fact differ by only a factor of 1.6. Conversion of these estimates to units of carbon (using conversion of Parsons et al, 1967) indicates that about 9.2 and $15 \mathrm{~g} \mathrm{C}$ $\mathrm{m}^{-3} \mathrm{yr}^{-1}$ are being removed by the tintinnids and copepods of central Long Island Sound. Riley's esti- 
mate (1956) of Long Island Sound's primary production (currently the best available estimate) suggests a rate of $34 \mathrm{~g} \mathrm{C}$ fixed $\mathrm{m}^{-3} \mathrm{yr}^{-1}$ (assuming a $6 \mathrm{~m}$ euphotic zone; Capriulo and Carpenter, 1980). Thus, the tintinnids and copepods of central Long Island Sound are removing about $27 \%$ and $44 \%$ of the annual primary production, respectively.

It should be pointed out that Tintinnidium fluviatile, at times during the summer quite abundant, was not included in these calculations since poor preservation prevented estimation of precise numerical abundance. Inclusion of this large-sized species in the above calculations would have raised the yearly ingestion estimate for the tintinnids. Also, naupliar stage copepods were not considered in the above estimates, nor were ciliates other than tintinnids (which at times reach concentrations as high as $50000 \mathrm{I}^{-1}$ in Long Island Sound surface waters; McManus, unpubl). Lastly, differences exist in the methods of collection of the tintinnids and copepods for abundance estimates. Tintinnids were collected in 10-l Niskin bottles while copepods were collected in vertical tows. How these differences in sample collection might alter the above estimates of yearly ingestion is presently unknown. Unpublished data of G. McManus does, however, indicate that tintinnids are approximately uniformly distributed with depth in central Long Island Sound.

These findings demonstrate that tintinnids are a major herbivore group in central Long Island Sound; they confirm, for a yearly cycle, the findings of Capriulo and Carpenter (1980) that ingestion of phytoplankton by tintinnids is significant relative to the copepod ingestion rate

Acknowledgements. This research was supported in part by a fellowship from the Jessie Smith Noyes Foundation; by a grant from the Lerner Foundation for Marine Research; by MESA (NOAA); and by a grant from the New York State Department of Environmental Conservation. We wish to thank Drs. J. F. Heinbokel, R. Armstrong, K. Gold and R. Malouf for valuable criticism regarding this work.

\section{LITERATURE CITED}

Baker, C., Phaff, W. J. (1976). Tintinnida from coastal waters of the southwest Netherlands. 1. The genus Tintinnopsis. Hydrobiologia 50: 101-111

Beers, J. R., Reid, F. M. H., Stewart, G. L. (1980). Microplankton population structure in southern California nearshore waters in late spring. Mar Biol. 60: 209-226

Beers, J. R., Stevenson, M. R., Eppley, R. W., Brooks, E. R. (1971). Plankton populations and upwelling off the coast of Peru, June 1969. Fish. Bull. U. S. 69: 859-876.

Beers, J. R., Stewart, G. L. (1967). Micro-zooplankton in the euphotic zone at five locations across the California current. J. Fish. Res. Bd Can. 24: 2053-2068.

Beers, J. R., Stewart, G. L. (1969). Micro-zooplankton and its abundance relative to the larger zooplankton and other seston components. Mar. Biol. 4: 182-189

Beers, J. R., Stewart, G. L. (1971). Micro-zooplankters in the plankton communities of the upper waters of the Eastern Tropical Pacific. Deep Sea Res. 18: 861-883

Capriulo, G. M. (1982). Feeding of field collected tintinnid micro-zooplankton on natural food. Mar Biol. 71: 73-86

Capriulo, G. M., Carpenter, E. J. (1980). Grazing by 35 to 202 $\mu \mathrm{m}$ micro-zooplankton in Long Island Sound. Mar. Biol. 56: $319-326$

Capriulo, G. M., Gold, K., Okubo, A. (1982). Evolution of the lorica in tintinnids: a possible selective advantage. Annls Inst. océanogr., Paris 58 (S)

Capriulo, G. M., Ninivaggi, D. V (1982). A comparison of the feeding activities of field collected tintinnids and copepods fed identical natural particle assemblages. Annls Inst. océanogr., Paris 58 (S)

Conover, S. A. M. (1956). Oceanography of Long Island Sound, 1952-1954. IV Phytoplankton. Bull. Bingham. Oceanogr. Coll. 15: 62-112

Cushing, D. H., Humphrey, G. F., Banse, K., Laevastu, T. (1958). Committee on terms and equivalents. Rapp. P.-v. Réun. Cons. int. Explor. Mer 144: 15-16

Davis, C. C. (1981). Variations of lorica shape in the genus Ptychocylis (Protozoa: Tintinnina) in relation to species identification. J. Plankt. Res. 3: 433-443

Deevey, G. B. (1956). Oceanography of Long Island Sound, 1952-1954 V Zooplankton. Bull. Bingham Oceanogr. Coll. 15: 113-155

Fornshell, J. A. (1979). Microplankton patchiness in the northwest Atlantic Ocean. J. Protozool. 26: 270-272

Gillbricht, M. (1954). Das Verhalten von Zooplankton - vorzugsweise von Tintinnopsis beroidea Entz - gegenüber thermohalinen Sprungschichten. Kurze Mitt. Inst. Fisch Biol. Univ. Hamb. 5: 32-44

Gold, K., Morales, E. A. (1975). Seasonal changes in lorica sizes and the species of Tintinnida in the New York Bight. J. Protozool. 22: 520-528

Gold, K., Morales, E. A. (1976). Studies on the sizes, shapes, and the development of the sizes, shapes, and the development of the lorica of agglutinated Tintinnida. Biol. Bull. mar biol. Lab., Woods Hole 150: 377-392

Hada, Ye (1932). Tintinnoinea from the Sea of Okhotsk and its neighborhood. J. Fac. Sci. Hokkaido Univ. Ser, 4 Zool. 2, No. 1

Halldal, P. (1953). Phytoplankton investigations from weather ship $M$ in the Norwegian Sea 1948-49. Hvalråd. Skr. 38: $1-91$

Halme, E. (1958). Planktologische Untersuchungen in der Pojo-Bucht und angrenzenden Gewässern. IV Zooplankton. Ann. Zool. Soc. 'Vaneno' 19: 1-62

Hargraves, P. E. (1981). Seasonal variations of tintinnids (Ciliophora: Oligotrichida) in Narragansett Bay, Rhode Island, USA. J. Plankt. Res. 3: 81-91

Hedin, H. (1976). On the ecology and cytology of tintinnids. Ph. D. dissertation, Institute of Zoology, University of Uppsala

Heinbokel, J. R. (1978a). Studies on the functional role of tintinnids in the Southern California Bight. I. Grazing and growth rates in laboratory cultures. Mar. Biol. 47: 177-189

Heinbokel, J. F. (1978b). Studies on the functional role of tintinnids in the Southern California Bight. II. Grazing rates of field populations. Mar. Biol. 47: 191-197

Heinbokel, J. F., Beers, J. R. (1979). Studies on the functional role of tintinnids in the Southern California Bight. III. Grazing impact of natural assemblages. Mar. Biol. 52: 23-32 
Hensen, V (1887). Uber die Bestimmung des Planktons oder des im Meere treibenden Materials an Pflanzen und Tieren. Ber dt. wiss. Komn Meeresforsch. 5: 1-108

Kimor, B., Golandsky, B. (1977). Microplankton of the Gulf of Elat: aspects of seasonal and bathymetric distribution. Mar. Biol. 42: 55-67

Kimor, B., Golandsky-Baras, B. (1981). Distribution and ecology of the tintinnids in the Gulf of Elat (Aqaba) Red Sea. J. Plankt. Res. 3: 445-459

Konovalova, G. V., Rogachenko, L. A. (1975). Species composition and population dynamics of planktonic infusorians (Tintinnina) in Amur Bay. Oceanology 14: 561-566

Laval-Peuto, M. (1981). Construction of the lorica in ciliate Tintinnina. In vivo study of Favella ehrenbergii: variability of the phenotypes during the cycle, Biology, Statistics, Biometry. Protistologia XVII, pp. 249-272

Lindley, J A. (1975). Continuous plankton records: a plankton atlas of the North Atlantic and North Sea: Supplement 3 - Tintinnida (Protozoa, Ciliophora) in 1965. Bull mar. Ecol. 8: 201-213

Lohmann, H. (1908). Untersuchungen. Zur Feststellung des vollständigen Gehaltes des Meeres und Plankton. Wiss. Meeresunters. (Abt. Kiel) 10: 131-370

Lund, J. W. G., Kipling, C., LeCren, E. D. (1958). The inverted microscope method of estimating algal numbers and the statistical basis of estimations by counting. Hydrobiologia 11: $143-170$

Margalef, R. (1982). Some thoughts on the dynamics of populations of ciliates. Annls Inst. Océanogr., Paris 58 (S)

Mayzaud, P., Poulet, S. A. (1978). The importance of the time factor in the response of zooplankton to varying concentrations of naturally occurring particulate matter. Limnol. Oceanogr. 23: 1144-1154

Morozovskaya, O. I. (1970). Shelled infusorians from the nearsurface layers of the pelagic zone of the Black Sea. In: Voprosy rybokhozyaystevennogo osvoyeniya i sanitarno biologicheskogo rezhima vodoyemov Ukrainy (Fishery development at sanitary biological conditions of bodies of water in Ukraine) Pt. 1, Krev. Naukova dumka

Motoda, S., Marumo, R. (1963). Plankton of the Kuroshio water Proc. Sympos. on the Kuroshio

O Connors, H. B., Jr., Biggs, D. C., Ninivaggi, D. V. (1980). Particle size-dependent maximum grazing rates for Temora longicornis fed natural particle assemblages. Mar. Biol. 56: 65-70

O'Connors, H. B., Small, L. F., Donaghay, P. L. (1976). Particle size modification by two size classes of the estuarine copepod Acartia clausi. Limnol. Oceanogr. 21: 300-308.

Parsons, T R., LeBrasseur, J. R., Fulton, J. D. (1967). Some observations on the dependence of zooplankton grazing on the cell size and concentration of phytoplankton blooms. J. oceanogr. Soc. Japan 23: 10-17

Riley, O. A. (1956). Oceanography of Long Island Sound, 1952-1954, IX. Production and utilization of organic matter. Bull. Bingham Oceanogr Coll. 15: 324-241

Sorokin, Y. I. (1977). The heterotrophic phase of plankton succession in the Japan Sea. Mar Biol. 47: 107-117

Strelkov, A. A. (1955). Class Infusoria, order Heterotricha, suborder Tintinnoinae. In: Atlas bespozyonochnykl dal' nevostochnykh morey SSSR (Atlas of invertebrates in the Far Eastern Seas of the USSR) Moscow-Leningrad, Izd. AN SSSR

Taniguchi, A. (1977). Biomass and size composition of copepod nauplii and tintinnids in the Philippine Sea and the Celebes Sea, summer 1972. Bull. Plankton Soc. Japan 24: $1-10$

Vitiello, P. (1964). Contribution a l'etude des tintinnides de la baie d'alger. Pelagos 2: 5-42

Zeitzschel, B. (1967). Die Bedeutung der Tintinnen als Glied der Nahrungskette. Helgoländer wiss. Meeresunters. 15 (1-4): 589-601

Zeitzschel, B. (1969). Tintinnen des westlichen Arabischen Meeres, ihre Bedeutung als Indikatoren für Wasserkörper und Glied der Nahrungskette. "Meteor" Forschungsergeb. D, 4, Biologie, 47-101 